\title{
The Repercussion of the Heating Degree-Days on Climate Changes in Big-Sized Cities - Case Study of the City of Belgrade
}

\author{
Duško Đukić1, Marina Nenković-Riznić2* \\ ${ }^{1}$ Faculty of Geography, Studentski Trg 3/III, Belgrade, Serbia \\ ${ }^{2}$ Institute of Architecture and Urban and Spatial Planning, Bulevar Kralja Aleksandra 73/II, Belgrade, Serbia
}

Received: 29 July 2021

Accepted: 22 November 2021

\begin{abstract}
The main objective of this manuscript is an analysis and a particular review of the heating degree-days for a long time period (1925-2018) in the big-sized cities. In this regard, daily air temperatures outside are important with stress on hourly and half-hourly values of air temperature which should facilitate the- determination of heating demands for different type of buildings. Multifarious criteria for calculating degree-days of heating and their comparison have been clarified. Different countries with different threshold temperature parameters for buildings of multifarious purposes were enumerated. There is noticeable decreasing of the values of heating degree-days in the big-sized cities, which is the result of climate changes. This is essential for intermittent heating of the households and office buildings, which is the instrument to prevent squander of energy. The regulation of threshold temperature with the aspect of thermal comfort of inhabitants has been considered, too. All of the paper's hypothesis were elaborated on the territory of the Serbia's capital city Belgrade.
\end{abstract}

Keywords: climate change, daily air temperature outside, threshold temperature, reference temperature, heating degree-days, Serbia

\section{Introduction}

The world has experienced sudden urban growth in last few decades. The growth rate of the Earth's urban population is greater than that of the total population, and therefore, urbanization has accelerated and reached enormous magnitude. In 1950, there were more than 20 cities over 1 million and 2 cities over 10 million inhabitants. In developed countries, nearly $53 \%$ of urban

*e-mail: marina@iaus.ac.rs population lived in cities, while about $15 \%$ of residents lived in urban areas of Third World countries. In 2007, there were more than 400 cities over 1 million and 19 cities over 10 million inhabitants. In the developed countries, about $74 \%$ of urban population lived in cities, while $44 \%$ of residents lived in urban areas of Third World countries [1].

The process of spontaneous urbanization was continued in the twenty-first century. In 2050, there will be approximately 1000 cities over 1 million and 27 cities over 10 million inhabitants. It is expected that $64 \%$ of the world population will be urban in the countries of Third World, while $86 \%$ of world 
population will be urban in developed countries by 2050 , so that most urban growth will occur in the developing countries [2].

Rapid urbanization has transformed natural environment natural into artificial environment. All of this resulted to development of urban heat island. Urban heat island is noteworthy phenomenon where urban area is usually warmer than surrounding countryside, particularly at nights. Hebbert [3] in his paper has mentioned Landsberg, Oke and Voogt who argued that urban heat island is one of the clearest and most widely documented phenomenon of inadvertent human impact on climate of cities. The exact form and intensity of that phenomenon varies from meteorological, local and urban features. Many studies about form and intensity are focused on big-sized cities, while deficit of urban heat island research in middle-sized towns are imminent, which it will be elaborated in next chapter.

\section{Earlier Theoretical Considerations}

This kind of topics which regards urban heat island and heating-degree days is attracting the attention a certain number of scientific researchers. The vast majority of scientific researchers had mainly dealt with the urban heat island of big-sized cities. Hebbert [3] in his paper has mentioned Kratzer who had studied the urban heat island of Berlin. Savić et al. [4] in his paper has mentioned Chandler who had studied urban heat island of London. Filho et al. [5] in his paper has mentioned Wilby who had studied urban heat island of London, too. Lorenz et al. [6] in his paper has mentioned Bornstein who had studied the urban heat island of New York. Zhou et al. [7] in his paper has mentioned Oke who had studied the urban heat island of Montreal. Rajogopalan et al. [8] in his paper has mentioned Ackerman who had studied the urban heat island of Chicago. Eastin et al. [9] in his paper has mentioned Jauregui who had studied the urban heat island of Mexico City. Chen et al. [10] in his paper has mentioned Longxun et al. who had studied the urban heat island of Shanghai. Liu et al. [11] in his paper has mentioned Shahmohamadi et al. who had studied the urban heat island of Tehran. Wang et al. [12] in his paper has mentioned Rinner and Hussain who had studied the urban heat island of Toronto. Lokoshchenko [13], as such as Varentsov et al. [14] in theirs paper had studied the urban heat island of Moscow. Qiao et al. [15] in his paper had studied the urban heat island of Beijing, Arifwidodo and Tanaka [16] in theirs paper had studied the urban heat island of Bangkok, whilst Wang et al. [17] in his paper had studied the urban heat island of Hong Kong. These studies about the urban heat island were created by model of Kratzer [3], Chandler [4], Wilby [5], Bornstein [6] and Oke [7]. Kratzer, Chandler and Oke were the pioneers in the studying of the urban heat island. They have established a closer determination of urban heat island, have described and explained the genesis of urban heat island and its consequences for the environment, have provided the possibilities of its mitigation in space and thus scientific framework for further researches that can be expanded as needed. These scientific researchers also have simply exposed the matter about urban heat island and have applied not overcomplex methodology.

A small minority of scientific researchers had dealt with the urban heat island of middle-sized towns of former Eastern Bloc by model of Kratzer, Chandler, Wilby, Bornstein and Oke. Hrabak-Trumpa [18] had explored the urban heat island of Zagreb. Ivajnšič and Žiberna [19] in their paper have mentioned Unger who had explored the urban heat of Szeged, Droste et al. [20] in his paper has mentioned Fortuniak et al. who had explored the urban heat island of Lódź, Savić et al. [21] had explored the urban heat island of Novi Sad. Komac et al. [22] had explored the urban heat island of Ljubljana. Unger, Savić et al., Komac et al. have dealt with these topics and have conveyed methodology to the urban heat island of middle-sized towns, but they also have adjusted it with the aim of the repurposing space. The coverage of heating degree-days by modern scientific research primarily referred to the studies of heating degree-days in the megacities. In that respect, the following authors stand out: Belova et al. who had seriously dealt with heating-degree days of Moscow [23]. The author regards that the benchmark of the studying of the heating-degree days is paper Belova et al. [23] for the reason of actuality and intelligibility. The methodology of above mentioned authors has its own advantages, since it can be applied to more complex researches of the subject matter. Consequently, this scientific issues is more or less determined by clear guidelines.

The first of the aims of this manuscript is to link fluctuations of the value of heating degree-days (HDD) and the number of heating days (Z) with climate changes, as well climate changes with rapid urbanization in big-sized cities. The second of the aims of that manuscript is to establish new criteria of threshold temperature for heating up buildings of multifarious purposes, new values of temperature for interior rooms of the household, as well as finally the installation automated heating according to the effect of consumption, regardless of whether it is heating season or not. The third of the goals of this manuscript is revision of database for $\mathrm{HDD}$ and $\mathrm{Z}$.

The effect of heating threshold temperature and inside air temperature in frame of $\mathrm{Z}$ has been analyzed. The selection of threshold temperature is fundamental question for HDD - based analysis. HDD will be solely accumulated when the outside air temperature drops below the heating threshold temperature. Different countries have got different threshold temperature regulations, such as $15.5^{\circ} \mathrm{C}$ in the United Kingdom of Great Britain [24], $12.0^{\circ} \mathrm{C}$ in Serbia [25], in Switzerland the situation is specific [26], while in the Russian Federation threshold temperature amounts only $8.0^{\circ} \mathrm{C}$ [29]. It can be said that the threshold temperature 
of heating is result of the mean daily outside temperature for multiannual period. Availability of the mean daily values of the outside temperature makes it easy to calculate the HDD and quantify $\mathrm{Z}$.

De facto, there are no unique criteria for calculating HDD and their comparison, already few of them exist, which are applied differently from the country to the country. In the United Kingdom of Great Britain (UK) one criterion is valid for calculating HDD and their comparison [24], while in the Swiss Confederation $(\mathrm{CH})$ the second criterion [26]. According to Živković and Novoselac the third criterion is valid in the Republic of Serbia (RS) [25], while according to Belova et al. [23] the fourth criterion is valid in the Russian Federation (RF). Their features will be explained in detail to the following section.

The pilot area of this study will be Belgrade, Serbia.

\section{Materials and Methods}

\section{Heating Degree-Days (HDD) and the Number of Heating Degree-Days (Z)}

According to Živković and Novoselac [25] heating degree-days $(H D D)$ and the number of heating days $(Z)$ belong to the simplest and the most appropriate way to quantify heating demands for different edifices, which is particularly important for planning process. They represent simplified format of historical weather data, too. In hitherto domestic practice, values of $H D D$ and $Z$ have been quantified based on average monthly air temperatures. Thus, using daily average air temperatures, it is possible to apply different criteria to calculate $H D D$ and to determine $Z$. Values of $H D D$ were derived from synoptic measurements air temperature outside relative to threshold temperature for heating, as well as threshold temperature for heating relative to reference temperature of interior premises. Threshold temperature for heating is outside temperature above which a building needs no heating, while reference temperature for interior premises is traditional temperature based on thermal comfort of people. These values were calculated by empirical equation for $H D D$ $[25,27]$. $Z$ was gained from tautology of measured air temperature outside relative to threshold temperature for heating. If a daily mean outside air temperature is lower than the threshold temperature $\left(t_{g}<12.0^{\circ} \mathrm{C}\right)$, the $Z$ equal to 1 , otherwise $\left(t_{g} \geq 12.0^{\circ} \mathrm{C}\right)$ the $Z$ is equal to 0 . The empirical equation for $H D D$ is:

$$
H D D=Z \cdot\left(t_{u}-t_{s n}\right)
$$

where $Z$ is the number of heating days, $t_{u}$ is reference temperatures of interior rooms and $t_{s n}$ is mean temperature of heating days. Lower values of $H D D$ indicate on shortening of heating period, while higher values of $H D D$ indicate on lengthening of heating period. Spinoni et al. points out that the $H D D$ were originally used as the sum of active temperatures in the growing season for phenological purposes, where threshold temperatures are $5.0^{\circ} \mathrm{C}, 10.0^{\circ} \mathrm{C}, 15.0^{\circ} \mathrm{C}$ and $20.0^{\circ} \mathrm{C}$ [28]. Furthermore, Shi et al. have labeled $H D D$ with ${ }^{\circ} \mathrm{D}[29]$, which will be applied it in next section.

From the reasons of accuracy, it should be aimed on appropriate data of $H D D$ and $Z$ from a weather station (which belongs the network of WMO and ICAO, respectively) near to the site you are analyzing, because it has high-quality temperature readings on every hour and half an hour. By the way, there are multifarious criteria to calculating HDD based on temperature readings in certain time period from the respective weather station, and their comparison in accordance with purpose.

First criteria to calculation HDD and their comparison were computed for mean monthly air temperature lower than threshold temperature. This criterion is widely applied, but it has many deficiencies [25].

Second criteria to calculation HDD and their comparison were computed as mean daily air temperature for three consecutive days. When mean daily air temperature for three consecutive days is below threshold temperature of heating, then heating starts up as late as following day [25]. If mean daily air temperature for three consecutive days is equal or higher from threshold temperature of heating, then heating stops following day. For these three consecutive days, HDD has just been calculated. That occasion prevails in the Republic of Serbia (RS). In the Russian Federation (RF) situation are different. When it's mean daily air temperature for five consecutive days below threshold temperature of heating, then heating starts following day [23]. If mean daily air temperature for five consecutive days is equal or higher from threshold temperature of heating, then heating stops following day. For these five consecutive days, HDD has just been computed.

Third criteria to calculation HDD and their comparison were computed daily mean air temperature for one day. When daily mean air temperature for one day is below threshold temperature of heating, then heating starts following day. If daily mean air temperature for one day is equal or higher from threshold temperature of heating, then heating stops following day [25]. For that day, HDD has just been calculated.

Fourth criteria to calculation HDD and their comparison are actual temperature at any given time. When actual air temperature is below threshold temperature of heating, then heating starts up immediately. If mean daily air temperature for one day is equal or higher from threshold temperature of heating, then heating stops immediately that day [25]. In this case appears intermittent heating. Day with actual temperature below threshold temperature of heating is taken into account for HDD. That implies an automatic system with multiple turning-on and turning-off over 
the day. This is applied in the United Kingdom of Great Britain (UK), as well as in the Swiss Confederation $(\mathrm{CH})$, where are specific circumstances, because there are the three variants of threshold temperature $\left(14.0^{\circ} \mathrm{C}\right.$, $\left.12.0^{\circ} \mathrm{C}, 10.0^{\circ} \mathrm{C}\right)[26]$.

\section{Research Methods}

The complexity of the researched topics has required lots of different methods: method of analysis, historiography method, statistical method and integral method [30]. Dahan-Dalmédico justifies this and highlights that the using these methods is of the key significance for meteorological studies. The method of analysis has been served to analyze the daily mean air temperature for multiannual period below of the threshold temperature of heating, as well as factorization $Z$. Historiography method has been contributed to the interpretation of historical documents about climate elements, such as daily mean air temperature for multiannual period. Statistical method had been calculated the numerical values of multiannual $H D D$, $Z$ and heating demand. Integral method has applied to turning raw temperature readings (on every hour or half-hours) into $H D D$. It has helped at generating detailed analysis of $H D D$, too. Boulanger et al. noticed that the quality control of climate data should contains syntax checks, consistency checks and logic-mathematical checks [31]. Syntax checks are manifested in punctuality of date and time performed measurements of air temperature, whereat same date and time measurement of air temperature should not occur twice. Consistency checks of climate date are manifested in absence of missing climate data, which means $100 \%$ coverage of daily meteorological data $(7 \mathrm{~h}$, $14 \mathrm{~h}$ and $21 \mathrm{~h}$ at local time). Logic-mathematical checks are manifested in tautology of measured air temperature outside, where has classified and taken into account air temperature below threshold temperature of heating (it was accepted $12.0^{\circ} \mathrm{C}$ in our case), so they are factored in $H D D$.

\section{Pilot Area - Belgrade, Serbia and Database}

Heating degree-days are the most pronounced in mega-cites and big-sized cities, so the majority of such researches reduced to them. Their perceptions have universal features, so they can be practiced even in middle-sized towns. In this survey, focus was on big-sized city, which is not thoroughly elaborated in scientific framework. For that purpose, Belgrade is chosen as surrogate of the big-sized cities. Belgrade is the biggest city in the central part of Republic of Serbia with 1166763 [32] in urbanized area of $359.96 \mathrm{~km}^{2}$ (Fig. 1). The geographic coordinates of the urbanized area in Belgrade are $44^{\circ} 44^{\prime}-44^{\circ} 54^{\prime} \mathrm{N}$ and $20^{\circ} 16^{\prime}-20^{\circ} 32^{\prime} \mathrm{E}$, which average altitude is $203 \mathrm{~m}$. The highest topographic point of this area is Kumodraž Repeater (335 m above sea level), while the lowest topographic point is Pančevo marshland $(71 \mathrm{~m}$ above sea level). The urban core and the vast of majority of city have developed on the most protruding Sumadija ridge which extending from Rudnik Mount (1132 m above sea level) to Kalemegdan Cape (115 m above sea level). Also, urban core and the vast of the majority of the city have spread have developed on Zemun loessial plateau (bounded by steep loess stretches towards the Danube and the Sava, relative heights 20-40 m), alluvial plain of the Danube (asymmetric character, 69-81 m above sea level), alluvial plain of the Sava (asymmetric character, 72-80 $\mathrm{m}$ above sea level), Pinosava fluvial - denudation plain (210-240 $\mathrm{m}$ above sea level), Terazije fluvial - denudation plain (140-160 m above sea level) and Bulbulder fluvial - denudation plain (110-120 $\mathrm{m}$ above sea level). This area has characterized Holocene sediments, Pleistocene sediments, Pliocene sediments, Miocene sediments and Late Cretaceous limestones. Therefore, the climate has strongly affected by orographic effects. According to Köppen-Geiger climate classification, Belgrade belongs Cfa climate (temperate warmly climate with a rather uniform annual distribution of precipitation, as well as tropic summer) [33]. In Belgrade, mean monthly air temperature in January amounts $0.6^{\circ} \mathrm{C}$, while mean monthly air temperature in July is $22.7^{\circ} \mathrm{C}$.

In this manuscript, daily frequency of air temperature values for the period 1925-2018, i.e. the last 94 years of measurements were used. Air temperature values, measured at $2 \mathrm{~m}$ above the ground, were provided from Belgrade (Vračar)

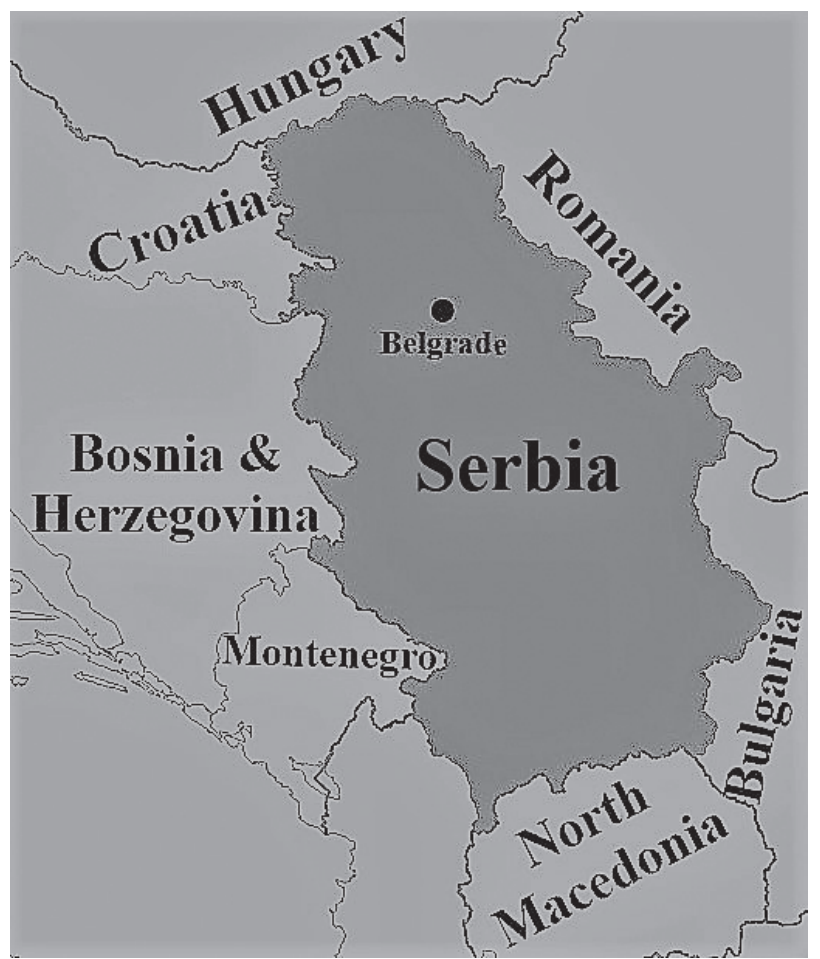

Fig. 1. Geographic position of the Republic of Serbia and the capital city Belgrade. 


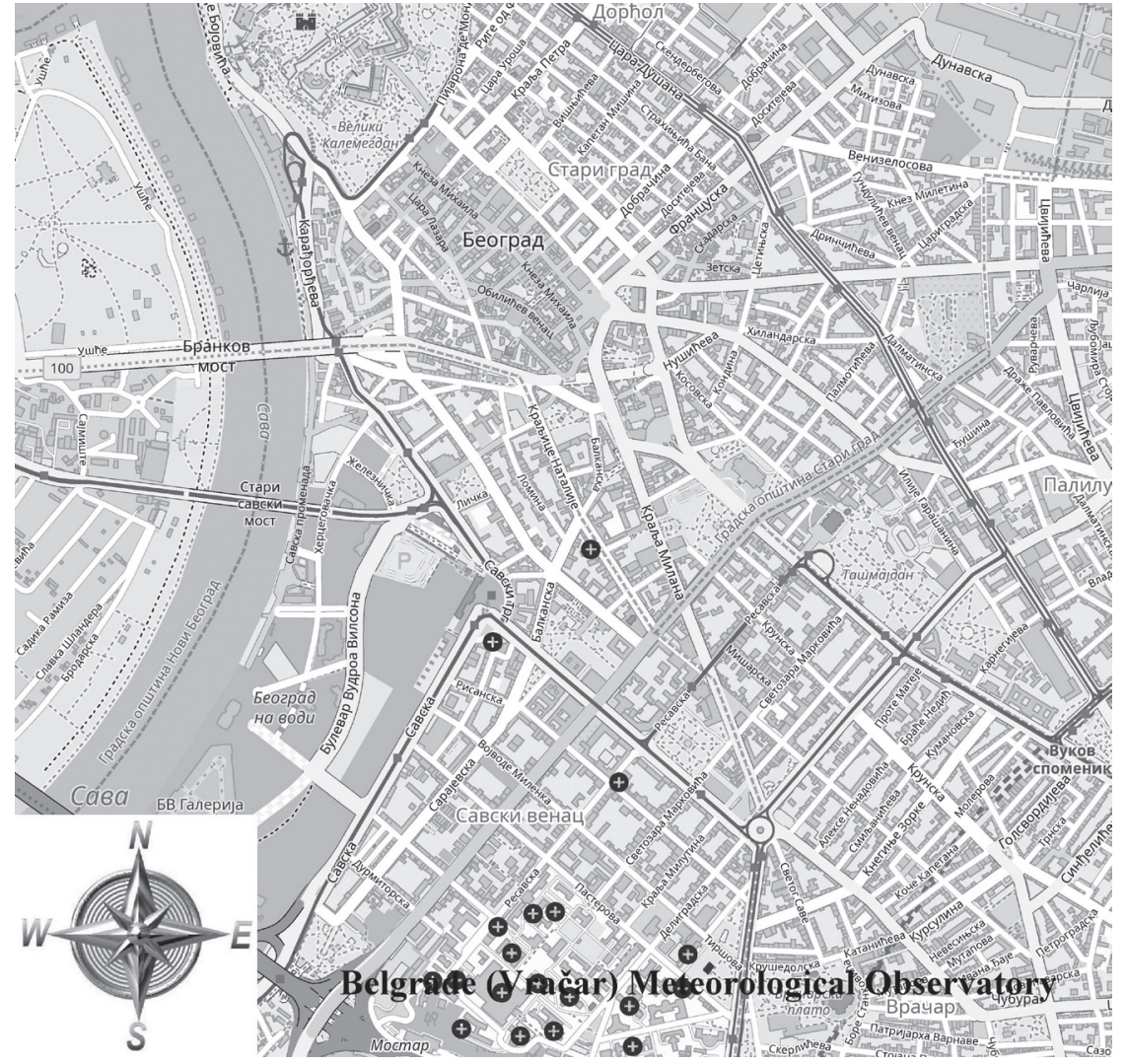

Fig. 2. The site of Vračar Meteorological Observatory in Belgrade.

Meteorological Observatory (ID 13274), which is situated on Vračar plateau, $2000 \mathrm{~m}$ from the old city core southeastern $\left(44^{\circ} 48^{\prime} \mathrm{N}\right.$ and $20^{\circ} 28^{\prime} \mathrm{E}, 132 \mathrm{~m}$ above sea level) (Fig. 2).

In the analysis, three time periods were randomly selected of HDD (1941-1948, 1969-1978, 1996-2018), while three time periods of $H D D$ (1925-1940, 19491968, 1979-1995) were preselected by Todorović [34] and Živković and Novoselac [25] where they have meticulously studied $H D D$ for a given period, as well as targeted one cumulative time period of $H D D$ (1925-2018). It can be noticed that all these six time periods of $H D D$ are not uniformly. This has been done in such a way as to obtain as representative data for as long as possible.

\section{Results and Discussion}

\section{Results}

For analyzing and interpreting of $H D D$ results, linear regression and student's t-test have been applied. Fisher emphasizes that linear regression is a sophisticated way for comparing and ranking of the trends of $H D D$ [35]. It is so useful for inferring causal relationships of $H D D$. Gosset (1908) found out that Student's t-test is a parameter of significance null hypothesis (sample size must be at least 30), i.e., checking whether there is a statistically significant difference or not [36]. It is really applicable for long series of meteorological data with a few of unknown values.

As mentioned above, there are six time periods of $H D D$ here. Three time periods of HDD (1941-1948, 1969-1978, 1996-2018) have randomly selected, but time periods of $H D D(1925-1940,1949-1968)$ was preselected by Todorović [34], while time period (1979-1995) were preselected by Živković and Novoselac [25], where they have meticulously studied HDD for a given period. Furthermore, all meteorological elements and phenomena in one-hour periods with inappreciable interruptions have been registered, starting from 1925 until present days. As above mentioned, there are six time periods of $H D D$ here. Besides these six time periods, cumulative time period of $H D D$ was represented. These time periods have been used, in order to actually perform an appropriate comparison and analysis of values by linear regression and student t-test, where the logic of complementary sets would valid.

The first period of the $H D D$ was lasting sixteen years. For this period, the maximum of $H D D$ was at the beginning $\left(3231.0^{\circ} \mathrm{D}\right)$ and on the end $\left(3231.3^{\circ} \mathrm{D}\right)$ of this time period, which was a joint of maximum values of relative deviation from average (20.3\%); while the minimum HDD was in $1934\left(2187.8^{\circ} \mathrm{D}\right)$, in the middle of this time period (Fig. 3). The average value of HDD for that time period was amounted $2686.7^{\circ} \mathrm{D}$. 


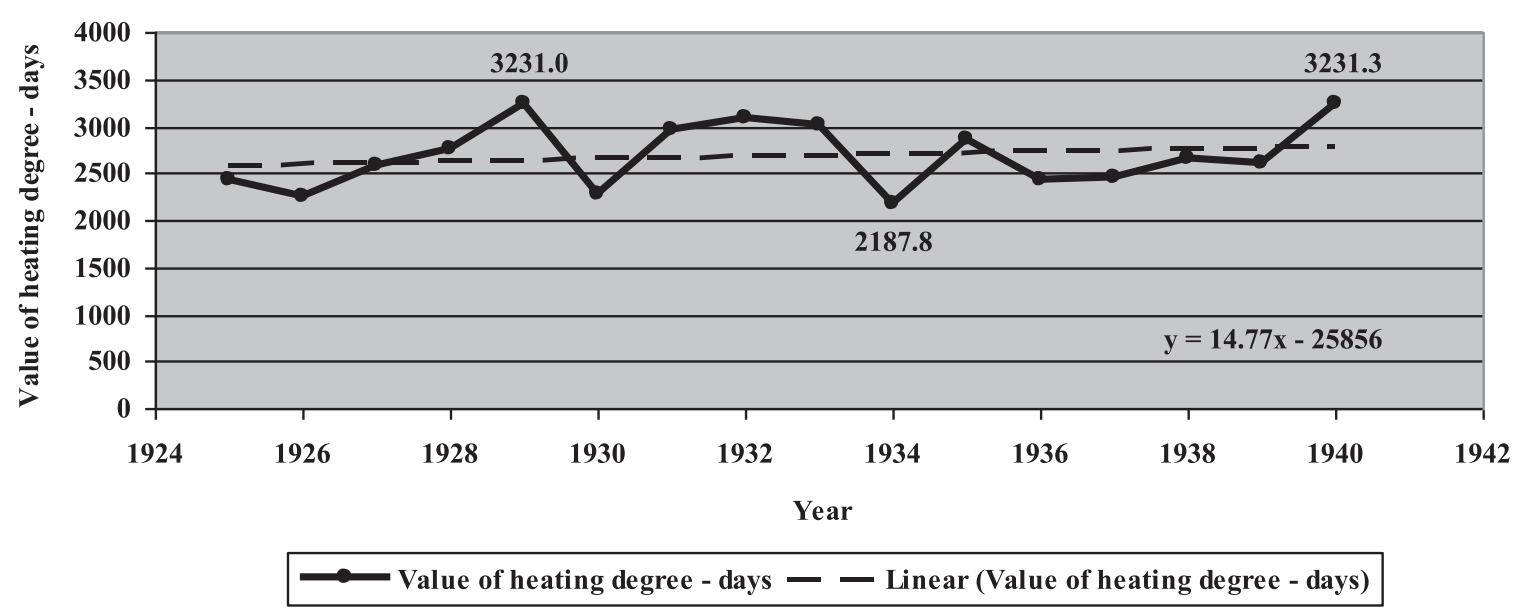

Fig. 3. Linear regression with trend-line of heating degree-days for time period 1925-1940.

Source: Đukić and Nenković-Riznić

As it can be perceived, the $H D D$ trend slope (HDD per year) has amounted -14.77 , meaning that the $H D D$ has decreased by 14.77 per year (Fig. 3).

The second period of the $H D D$ was lasting eight years. For that period, the highest value of $H D D$ was at the beginning $\left(2960.9^{\circ} \mathrm{D}\right)$ of that time period, which was a joint of maximum values of relative deviation from average (10.2\%); likewise the lowest value of $H D D$ was at the beginning $\left(2468.9^{\circ} \mathrm{D}\right)$ of that time period (Fig. 4). The average value of $H D D$ for this time period amounted $2686.3^{\circ} \mathrm{D}$.

As it can be noticed, the $H D D$ trend slope (HDD per year) has amounted -39.883 , meaning that the HDD has decreased by 39.883 per year (Fig. 4).

The third period of the $H D D$ was lasting twenty years. For this period, the maximum $H D D$ was in $1956\left(3141.6^{\circ} \mathrm{D}\right)$, which was a joint of maximum values of relative deviation from average (21.6\%); while the minimum $H D D$ was in $1961\left(2186.0^{\circ} \mathrm{D}\right)$ (Fig. 5). The average value of $H D D$ for that time period amounted $2582.6^{\circ} \mathrm{D}$.
As it can be perceived, the $H D D$ trend slope (HDD per year) has amounted -0.7844 , meaning that the $H D D$ has decreased by 0.7844 per year (Fig. 5).

The fourth period of the $H D D$ was lasting ten years. For that period, the highest value $H D D$ was at begging $\left(2776.9^{\circ} \mathrm{D}\right)$ of that time period; while the lowest value of $H D D$ was on the end $\left(2371.9^{\circ} \mathrm{D}\right)$ of that time period, which was a joint of maximum values of relative deviation from average (8.1\%) (Fig. 6). The average value of $H D D$ for this time period amounted $2580.4^{\circ} \mathrm{D}$.

As it can be noticed, the $H D D$ trend slope $(H D D$ per year) has amounted -15.833 , meaning that the $H D D$ has decreased by 15.833 per year (Fig. 6).

Fifth period of the $H D D$ was lasting seventeen years. For this period, the maximum $H D D$ was in 1980 $\left(2846.0^{\circ} \mathrm{D}\right)$; while the minimum $H D D$ was in 1990 $\left(2089.8^{\circ} \mathrm{D}\right)$, which was a joint of maximum values of relative deviation from average (17.6\%) (Fig. 7). The average value $H D D$ for this time period amounted $2537.1^{\circ} \mathrm{D}$.

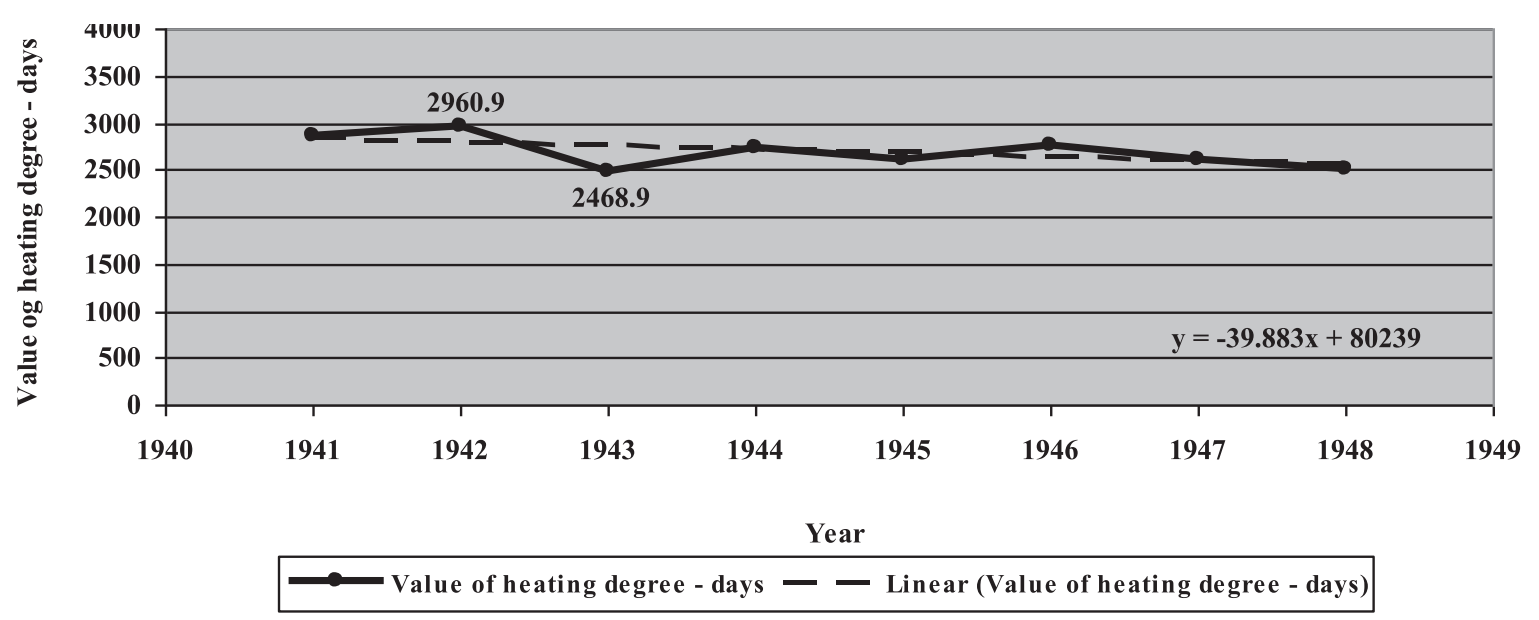

Fig. 4. Linear regression with trend-line of heating degree-days for time period 1941-1948.

Source: Đukić and Nenković-Riznić 


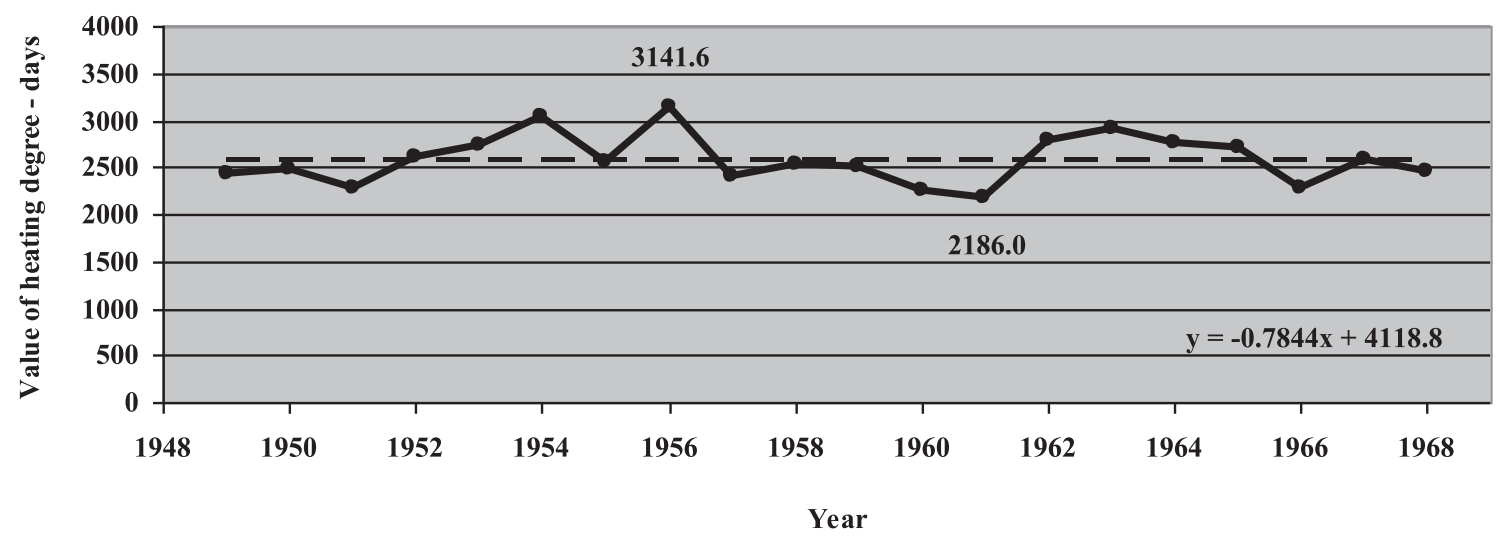

$\longrightarrow$ Value of heating degree - days $-\longrightarrow$ Linear (Value of heating degree - days)

Fig. 5. Linear regression with trend-line of heating degree-days for time period 1949-1968.

Source: Đukić and Nenković-Riznić

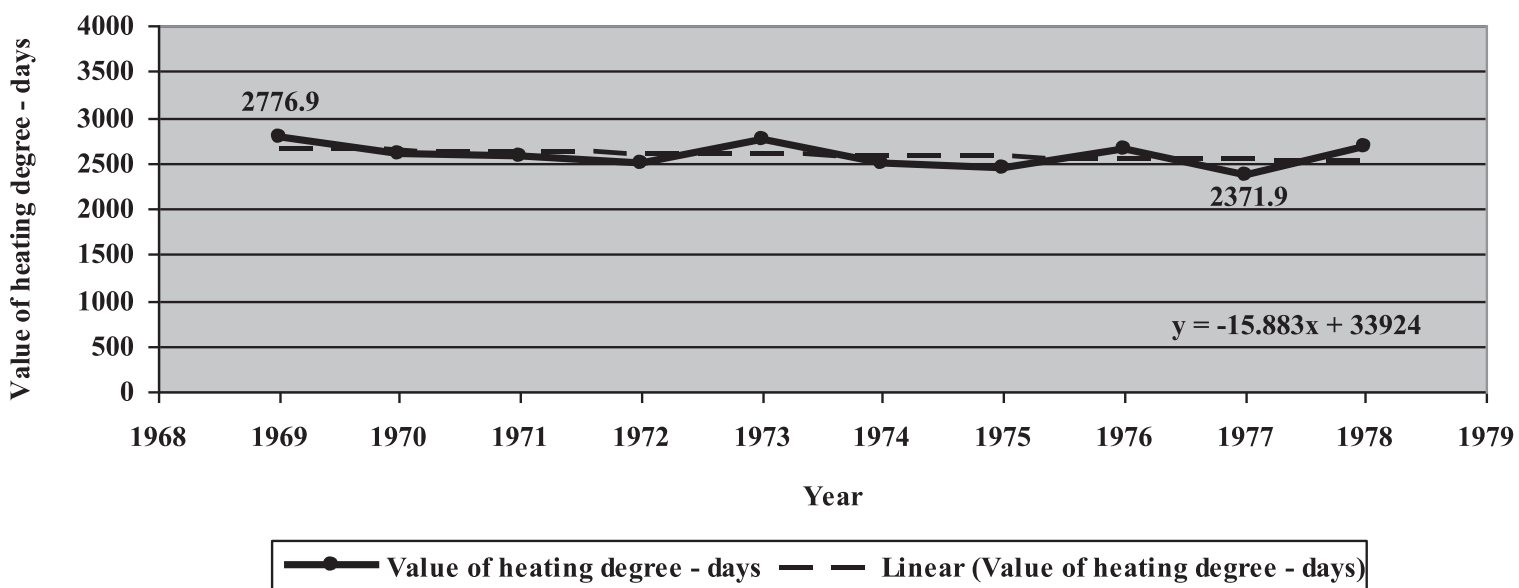

Fig. 6. Linear regression with trend-line of heating degree-days for time period 1969-1978.

Source: Đukić and Nenković-Riznić

As it can be perceived, the $H D D$ trend slope $(H D D$ per year) has amounted -12.005 , meaning that the HDD has decreased by 12.005 per year (Fig. 7).

The sixth period of the HDD was lasting twenty three years. For that period, the highest value of HDD was in $1996\left(2727.9^{\circ} \mathrm{D}\right)$ of that time period, which was a joint of maximum values of relative deviation from average (19.3\%); while the lowest value of $H D D$ was in $2014\left(1871.9^{\circ} \mathrm{D}\right)$ of that time period (Fig. 8). The average value of $H D D$ for this time period amounted $2287.4^{\circ} \mathrm{D}$.

As it can be noticed, the $H D D$ trend slope (HDD per year) has amounted -17.277 , meaning that the HDD has decreased by 17.277 per year (Fig. 8).

Cumulative period of the $H D D$ was lasting ninetyfour years. For this period, the highest values of $H D D$ were in $1940\left(3231.3^{\circ} \mathrm{D}\right)$ and $1929\left(3231.0^{\circ} \mathrm{D}\right)$, which was a joint of maximum values of relative deviation from average (27.6\%); while the lowest values of $H D D$ were in $2014\left(1871.9^{\circ} \mathrm{D}\right)$. It can be observed that the highest values of $H D D$ have recorded at the begging of this targeted period, while the lowest values of $H D D$ have recorded on the end of this targeted period (Fig. 9). The average value of $H D D$ for this time period amounted $2528.5^{\circ} \mathrm{D}$.

The $H D D$ trend slope (HDD per year) has amounted -5.2306 , meaning that the HDD has decreased by 5.2306 per year (Fig. 9).

This cumulative period of $H D D$ was also subject to the student's t-test. According to this testing, sample size was 94, degrees of freedom were 93, test statistics had amount -0.8856 , test static of two-tailed test for probability 0.05 was approximately 1.9858 , test static of two-tailed test for probability 0.01 had amount approximately 2.6297 , the probability value of two-tail test was 0.3781 . This means that the results were not statistically significant with risks lower than 5\% and $1 \%$, respectively.

A decreasing trend of the $H D D$ and $Z$ for cumulative time period (1925-2018) was presented.. The third time 


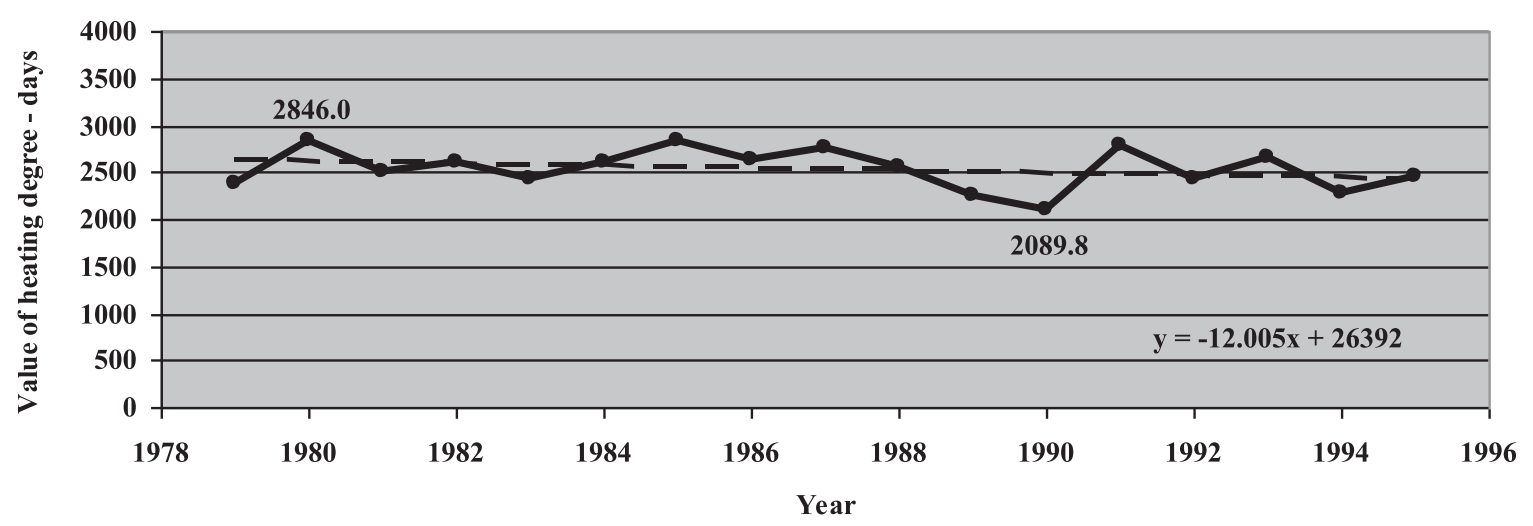

$\rightarrow$ Value of heating degree - days - - Linear (Value of heating degree - days)

Fig. 7. Linear regression with trend-line of heating degree-days for time period 1979-1995.

Source: Đukić and Nenković-Riznić

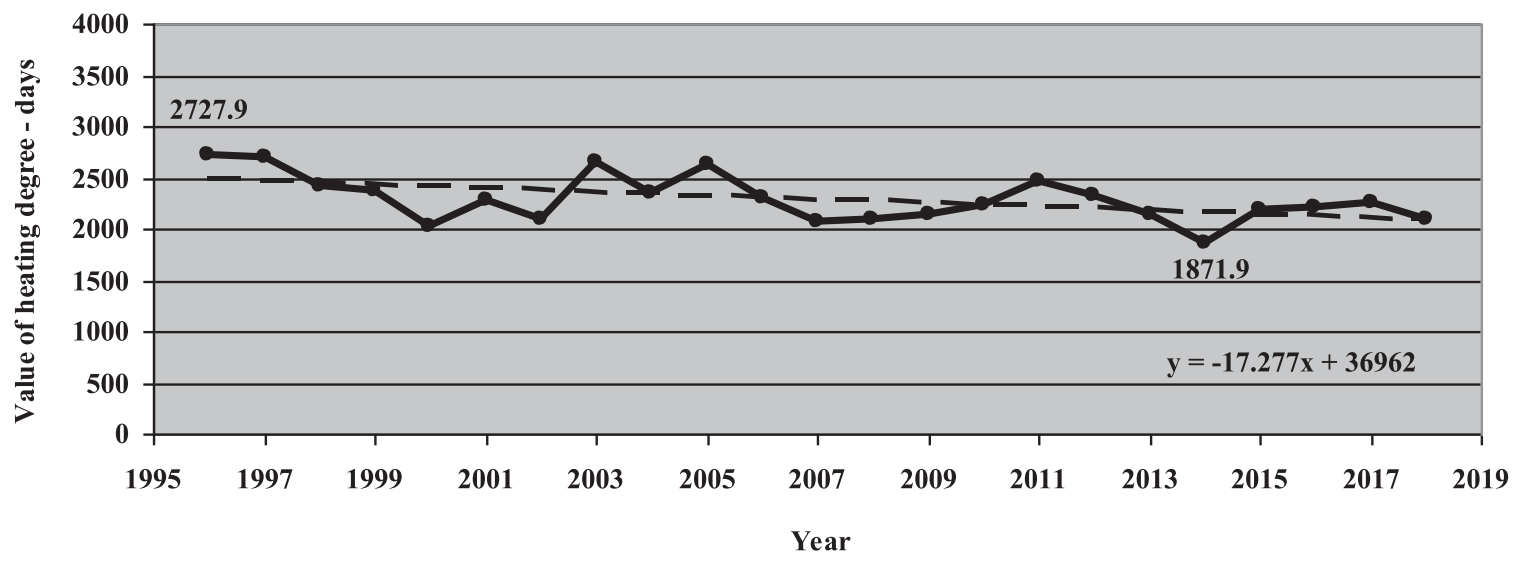

$\rightarrow$ Value of heating degree - days -- Linear (Value of heating degree - days)

Fig. 8. Linear regression with trend-line of heating degree-days for time period 1997-2018.

Source: Đukić and Nenković-Riznić

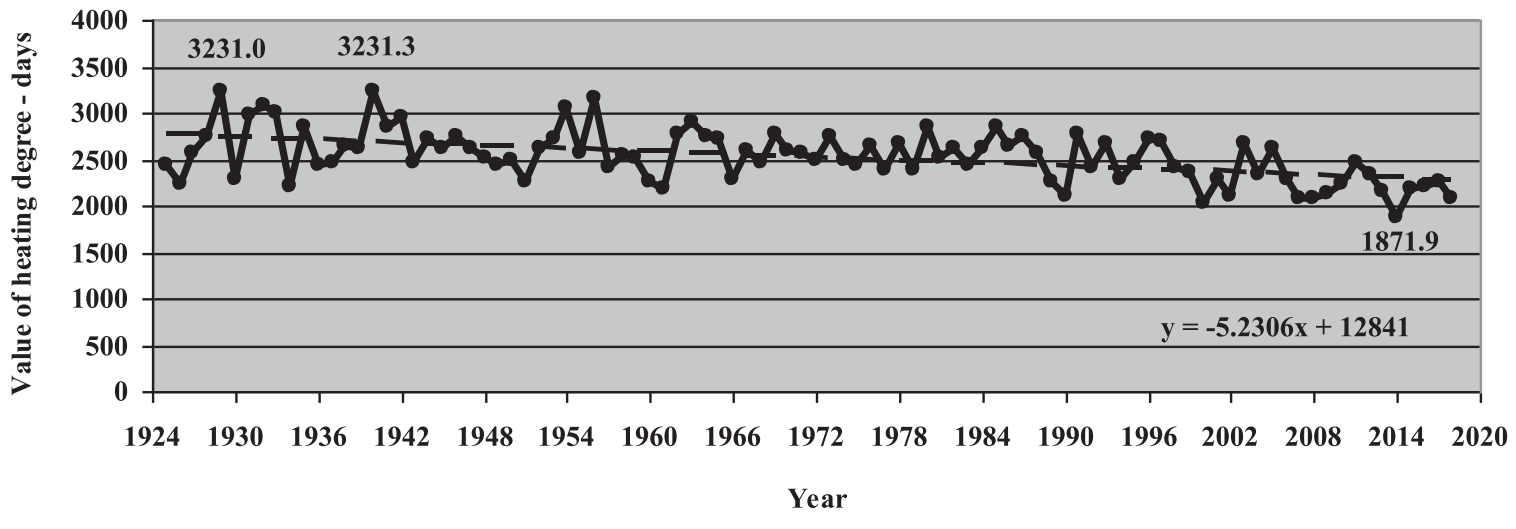

$\rightarrow$ Value of heating degree - days - Linear (Value of heating degree - days)

Fig. 9. Linear regression with trend-line of heating degree-days for cumulative time period 1925-2018.

Source: Đukić and Nenković-Riznić 
period (1949-1968) was the longest with the smallest decreasing of the $H D D$ and $Z$. The sixth time period (1996-2018) was the longest one with the biggest decreasing trend of $H D D$ and $Z$. The decreasing trend of the $H D D$ and $Z$, very likely, is a result of climate changes. This was supported by the fact that the average air temperature on the planet has increased by $0.76^{\circ} \mathrm{C} \pm 0.19^{\circ} \mathrm{C}$ since the late of $19^{\text {th }}$ century, which has primarily caused by rising in concentrations carbon dioxide, water vapor and methane [37].

\section{Discussion}

The key issue is at which outside temperature should be started to heating up of the apartments and offices, as well as application of different parameters for $H D D$ at buildings of diverse purposes in big cities and middlesized towns. In the terms of the start of heating, it must be considered after what time the facilities for heating should be started whence as the outside temperature drops below the heating threshold temperature. Todorovic found the coldest temperature has often being in households and office buildings during transitional periods (late spring and early autumn), wherefore putting in operation central heating system was just then exacting [38]. Based on Decision of heat energy supplying in the City of Belgrade [39], the heating season lasts from $15^{\text {th }}$ October the previous year until $15^{\text {th }}$ April the following year. If it befalls the threshold temperature be lower than $12.0^{\circ} \mathrm{C}$ out of heating season, then users would surely be disadvantaged as regards of the heat energy, despite the fact that they pay not really small heating costs during the entire calendar year. Numerous complaints by citizens of Belgrade (Serbia) [40, 41], Niš (Serbia) [42] and Banja Luka (Republic of Srpska) [43] about supplying of heating energy speak in favor of that. The management of the city heating plants has looking for justification within dilapidation of distributive hot water network. In such circumstances, when users already pay not really small heating costs throughout the entire calendar year, then these defects should be remedied. It is suggested to increase threshold temperature of heating by $1.0^{\circ} \mathrm{C}$, so that the threshold temperature of heating would now be $13.0^{\circ} \mathrm{C}$. At moving up threshold temperature of heating by $1.0^{\circ} \mathrm{C}$, the value of $H D D$ increased approximately by $2 \%$. Likewise, when the reference temperature of interior rooms rises by $1.0^{\circ} \mathrm{C}$, the energy consumption of heating increases by about 7\%. These assertions have been corroborated by Živković and Novoselac [25].

In the respect of application of different parameters for $H D D$ at buildings of diverse purposes in big-sized cities and middle-sized towns (Belgrade), it is quite justified the implementation of heating parameters, such as those in the Swiss Confederation. It would be worth pointing out that the reference temperatures of interior rooms in the $\mathrm{UK}$ amounts $20.0^{\circ} \mathrm{C}$, in the RS is $19.0^{\circ} \mathrm{C}$, while in the $\mathrm{RF}$ amounts $18.0^{\circ} \mathrm{C}$. However, in the Swiss Confederation, there are three different reference temperatures of interior rooms and three threshold temperatures for multifarious buildings [26]. At hospitals, kindergartens and nursing homes, reference temperature for interior rooms has amount $22.0^{\circ} \mathrm{C}$ and threshold temperature of heating has amount $14.0^{\circ} \mathrm{C}$. At residential buildings and business edifices, reference temperature for interior rooms has amount $20.0^{\circ} \mathrm{C}$ and threshold temperature of heating has amount $12.0^{\circ} \mathrm{C}$. While, at warehouses, reference temperature for interior rooms has amount $18.0^{\circ} \mathrm{C}$ and threshold temperature of heating has amount $10.0^{\circ} \mathrm{C}$. In fact, these reference temperatures and threshold temperatures can be elucidated under a cloak of the level of economic development, civil engineering practice, climatic conditions, and somewhat, living habits of users.

\section{Conclusions}

In the light of climate changes, it is about time to perform long-term analysis and revision the values of $H D D$ and $Z$ for big-sized cities, as well as introducing certain modification to the database of $H D D$ and $Z$. This has justified by the trend of decreasing $H D D$ and $Z$. On the other hand, it should be accessed the increasing of threshold temperature for heating by $1.0^{\circ} \mathrm{C}$, whereas researching by this procedure has shown slightly magnification of the values $H D D$ and energy consumption of heating. With the aspect of thermal comfort of habitants, presumption is that it would be smartly at least installed the calorimeters in buildings of diverse purposes in Belgrade, where the set point temperature could be regulated according to sensation, but also pay as much as you squander energy. That implies an automatic system with multiple turning-on and turning-off over the day. In this way, it can make a significant contribution to reducing anthropogenic impact on climate changes in future time. The paper has confirmed that HDD are inexhaustible topic for applicative climatology. The possibility of the improving material would be reflected in the usage of the other climatic parameters (except Air Temperature expressed in Celsius degrees or in Fahrenheit degrees), such as Global Solar Radiation on horizontal surface (expressed in $\mathrm{W} / \mathrm{m}^{2}$ ), Wind course (with eight or sixteen directions) with Wind speed (expressed in $\mathrm{m} / \mathrm{s}$ or in knots), Air Relative Humidity (expressed in percentage) and Cloudiness (expressed in tithes or in octas). Likewise, the possibility of enhancing the methodology would be reflected at application the reliable model of the forecasting heating degree-days in the future.

The lack of research relates on the impossibility of implementation a field survey of the users of central heating, especially in respect of scope, wording and format. Opening of the new spaces for research should be directed towards the users thermal comfort of central 
heating and their life habits in the big-sized cities, such as Belgrade.

\section{Conflict of Interest}

The authors declare that there are no conflicts of interest regarding the publication of this paper.

\section{References}

1. POPULATION REFERENCE BUREAU, 2020. Available online: https://www.prb.org (accessed on $10^{\text {th }}$ April 2021).

2. WORLD BANK, 2020. Available online: http://www. worldbank.org (accessed on $10^{\text {th }}$ April 2021).

3. HEBBERT M. Climatology for city planning in historical perspective. Urban climate, 10, 204215, 2014.

4. SAVIĆ S., MILOŠEVIĆ D., LAZIĆ L., MARKOVIĆ V., ARSENOVIĆ, D., PAVIĆ D. Classifying Urban Meteorological Stations Sites by "Local Climate Zones": Preliminary Results for the City of Novi Sad (Serbia). Geographica Pannonica, 17 (3), 60, 2013.

5. FILHO W.L., ICAZA L.E., EMANCHE V.O., AL-AMIN A.Q. An Evidence-Based Review of Impacts, Strategies and Tools to Mitigate Urban Heat Islands. International Journal of Environmental Research and Public Health, 14 (12), 1, 2017.

6. LORENTZ J.M., KRONENBURG R., BERNHOFER C., NIYOGI D. Urban Rainfall Modification: Observational Climatology over Berlin, Germany. Journal of Geophysical Research: Atmospheres, 124 (2), 731, 2019.

7. ZHOU B., RYBSKI D., KROPP J.P. The role of city size and urban form in the surface urban heat island. Scientific reports, 7, 1, 2017.

8. RAJOGOPALAN P., LIM K.C., JAMEI E. Urban heat island and wind flow characteristics of a tropical city. Solar Energy, 107, 159, 2014.

9. EASTIN M.D., BABER M., BOUCHER A., DI BARI S., HUBLER R., STIMAC -SPALDING, B., WINESETT T. Temporal Variability of the Charlotte (Sub)Urban Heat Island. Meteorology and Climatology, 57 (1), 81, 2018.

10. CHEN L., JIANG R., XIANG W.N. Surface Heat Island in Shanghai and Its Relationship with Urban Development from 1989 to 2013. Advances in Meteorology, 1, 2015.

11. LIU Y., HUANG X., YANG Q., CAO Y. The turning point between urban vegetation and artificial surfaces for their competitive effect on land surface temperature. Journal of Cleaner Production, 292, 1, 2021.

12. WANG Y., BERARDI U., AKBARI H. The Urban Heat Island effect in the city of Toronto. Process Engineering, 118, 137, 2015

13. LOKOSCHENKO M.A. Urban 'heat island' in Moscow. Urban Climate, 10 (3), 550, 2014.

14. VARENTSOV M.I., KONSTANTINOV P.I., SHARTOVA N.V., SAMSONOV T.E., KARGASHIN P.E., VARENTSOV A.I., FENNER D., MEIER F. Urban heat island of the Moscow Megacity: the long-term trends and new approaches for monitoring and research based on crowdsourcing data. IOP Conference Series: Earth and Environmental Science, 606, 1, 2020.

15. QIAO Z., TIAN G., ZHANG L., XU X. Influences of Urban Expansion of Urban Heat Island in Beijing during 1989-2010, Advances in Meteorology 2014, 1, 2014.
16. ARIFWIDODO S.D., TANAKA T., The Characteristics of Urban Heat Island in Bangkok, Thailand. Procedia Social and Behavioral Sciences, 195, 423, 2015.

17. WANG W., ZHOU W., NG E.Y., XU Y. Urban heat islands in Hong Kong: statistical modeling and trend detection. Journal of International Society for the Prevention and Mitigation of Natural Hazards, 83 (2), 885, 2016.

18. HRABAK-TUMPA G. Some climatic characteristics of heating island of Zagreb. Zbornik meteoroloških i hidroloških radova SHMZ Jugoslavije, 14, 55, 1987 [In Serb-Croatian]

19. IVAJNŠIČ D., ŽIBERNA I., The effect of weather patterns on winter small city urban heat islands. Meterorological Applications, 26 (2), $195,2019$.

20. DROSTE A.M., STEENEVELD J.G., HOLTSLAG A.M. Introducing the Urban Heat Island Effect. Environmental Research Letters, 13, 1, 2018.

21. SAVIĆ S., UNGER J., GÁL T., MILOŠEVIĆ D., POPOV Z. Urban heat island research of Novi Sad (Serbia): A review. Geographica Pannonica, 17 (1), 32, 2013.

22. KOMAC B., CIGLIČ R., LOOSE A., PAVŠEK M., ČERMELJ S., OŠTIR K., KOKALJ Ž., TOPLOLE M. The Urban Heat Island in the Ljubljana City. In book Counteracting Urban Heat Island Effects in a Global Climate Change Scenario (Ed. Musco F.), Springer Nature: Cham, Swiss Confederation, 323, 2016.

23. BELOVA I.N., GINZBURG A.S., KRIVENOK L.A. Heating seasons length and degree days trends in Russian cities during last half century. Energy Procedia, 149, 373, 2018.

24. THE CHARTERED INSTITUTION OF BUILDING SERVICES ENGINEERS. Degree - days: theory and application, TM 41, London, The United Kingdom of Great Britain and Northern Ireland, 2006.

25. ŽIVKOVIĆ B., NOVOSELAC A. The criterium for calculating the number of degree - days. KGH Air conditioning, heating and cooling, 4, 45, 1998 [In Serbian].

26. SWISS FEDERAL OFFICE OF METEOROLOGY AND CLIMATOLOGY. Heating degree - days in Switzerland, Zürich, The Swiss Confederation, 2013.

27. JANKOVIĆ A., PODRAŠČANIN Z., ĐURĐEVIĆ V. Future climate change impacts on residential heating and cooling degree days in Serbia. Quarterly Journal of the Hungarian Meteorological Service, 123 (3), 351, 2019.

28. SPINONI J., VOGT J.V., BARBOSA P., DOSIO A., MCCORMICK N., BIGANO A., FÜSSEL H-M. Changes of heating and cooling degree - days in Europe from 1981 to 2100. International Journal of Climatology, 38 (1), 191, 2018.

29. SHI Y., GAO X., XU Y., GIORGI F. \& CHEN D. Effects of climate change on heating and cooling degree days and potential energy demand in the household sector in China. Climate Research, 67 (2), 135, 2016.

30. DALMÉDICO A.D. History and Epistemology of Models: Meteorology (1946-1963) as a Case Study. Archive for History of Exact Sciences, 55, 395, 2001.

31. BOULANGER J.P., AIZPURU J., LEGGIERI L., MARINO M. A procedure for automated quality control and homogenization of historical daily temperature and precipitation data $(\mathrm{APACH})$ : Part 1: quality control and application to the Argentine weather service stations, Climatic change, 98 (4), 471, 2010.

32. INSTITUTE FOR INFORMATICS AND STATISTICS OF BELGRADE. Statistical Yearbook of Belgrade 2012; Admiral Books: Belgrade, Serbia, 2012. 
33. BECK H.E., ZIMMERMAN N.E., MCVICAR T.R., VERGOPOLAN N., BERG A., WOOD E.F. Present and future Köppen - Geiger climate classification maps 1-km resolution, Sci Data 5, 180214 (2018). https://doi. org/10.1038/sdata.2018.214

34. TODOROVIĆ B. Climate and its influence on heating and air conditioning. KGH - Air conditioning, heating and cooling, 1, 61, 1975 [In Serb-Croatian].

35. FISHER R.A. The Influence of Rainfall on the Yield of Wheat at Rothamsted, Philosophical Transactions of the Royal Society B - Biological Sciences, 213, 89, 1925.

36. "STUDENT", GOSSET, W.S. The Probable Error of a Mean, Biometrika, 6 (1), 1, 1908.

37. INTERGOVERNMENTAL PANEL ON CLIMATE CHANGE (IPCC). Observations: Surface and Atmospheric Climate Change, Eds. Trenberht K.E., Jones P.D. Contribution of Working Group I to the Fourth Assessment Report of Intergovernmental Panel on Climate Change [Solomon S., Qin D., Manning M., Chen X., Marquis M., Averyt K., Tignor M.M., Miller H.L. (eds.)]. Cambridge University Press, Cambridge, The United Kingdom of Great Britain and New York, The United States of America, 2018.

38. TODOROVIĆ B., Projecting of the central heating plant, 11th ed.; Alliance of machine engineers, electrotechnical engineers and technicians (SMEITS): Belgrade, Serbia, 2009 [In Serbian].

39. DECISION OF HEAT ENERGY SUPPLYING IN THE CITY OF BELGRADE. The Official Gazette of City of
Belgrade, nos. 43/2007, 2/2011, 29/2014 and 19/2017, 2017 [Odluka o snabdevanju toplotnom energijom u gradu Beogradu - In Serbian].

40. NEWSPAPER ARTICLE: We have been paying all year, and we have freezing: The cancellation of central heating saves a 1000 euros per year, 2019, https://www.kurir.rs/ vesti/drustvo/3248169/placamo-cele-godine-a-mrznemo-se (accessed on $10^{\text {th }}$ April 2021).

41. NEWSPAPER ARTICLE: Do you know how it's like to sit at 19 degrees Celsius? 2020, https://www.danas.rs/dijalog/ pisma-citalaca/znate-li-kako-je-sedeti-na-19-stepeni/ (accessed on $10^{\text {th }}$ April 2021).

42. NEWSPAPER ARTICLE: When you say "goodbye" to the heating plant, 2017, https://www.dw.com/sr/kad-toplanikažeš-ćao/a-40988597 (accessed on $10^{\text {th }}$ April 2021).

43. NEWSPAPER ARTICLE: Heating started, radiators cold, 2012, https://www.banjaluka.com/drustvo/grijanje-poceloradijatori-hladni/ (accessed on $10^{\text {th }}$ April 2021).

44. FEDERAL HYDROMETEOROLOGICAL INSTITUTE OF YUGOSLAVIA. Meteorological data for Belgrade in time period 1925-1948, Belgrade, Federal People's Republic of Yugoslavia, 1952.

45. FEDERAL HYDROMETEOROLOGICAL INSTITUTE OF YUGOSLAVIA. Meteorological Yearbooks 1949-1985, Belgrade, Socialist Federal Republic of Yugoslavia, 1988.

46. REPUBLIC HYDROMETEOROLOGICAL SERVICE OF SERBIA. Meteorological Yearbooks 1986-2018, Belgrade, Serbia, 2019. 